\title{
Boredom coping in the context of secondary education ${ }^{1}$
}

\author{
Denisa Urbanová, Isabella Pavelková \\ Charles University, Faculty of Education, Department of Psychology
}

Received $2^{\text {nd }}$ July 2020 / final version received $28^{\text {th }}$ November $2020 /$ accepted $16^{\text {th }}$ March 2021

\begin{abstract}
The article concerns the problematics of the boredom experience and especially boredom coping in Czech secondary school students ( $n=460)$. The relationships between, on the one hand, reported boredom frequency, various aspects of state boredom experienced at school, trait boredom, grade point average and learning motivational characteristics and, on the other hand, different types of boredom coping strategies have been examined. Data were obtained using the Boredom Proneness Scale, Multidimensional State Boredom Scale, Coping with Boredom Scale, Learning Motivation Inventory and closed questions. Descriptive and inductive statistics were used to process the data. More and less risky boredom coping strategies were identified with regard to the boredom experience at school and grade point average. A key factor facilitating adaptive boredom coping appears to be the capability to find personal value in potentially boring tasks and to exert cognitive effort together with high levels of positive achievement motivation and conscientiousness with regard to schoolwork. Additionally, at least a certain level of cognitive motivation, which seems to be a key supportive factor, is needed. A risk factor with regard to rather maladaptive boredom coping appears to be the tendency to systematically employ avoidance or even escaping behavior. The results indicate that school boredom coping issues are very complicated and have numerous implications for further research.
\end{abstract}

Key words: boredom, school boredom, boredom coping, learning motivation

Boredom is described as a complex, subjectively strong aversive experience of lack of sense, will paralysis and perception of one's own situation as unsatisfactory that can be accompanied by a variety of mostly negative affective states of different intensity, such as sadness, anhedonia, apathy, agitation, frustration, and anger (Pavelkova \& Urbanova, 2018). However, the boredom experience also includes a certain potential for personal growth when it is well-managed. According to a certain group of researchers,

1 The study was supported by Charles University, project GA UK No. 846119.

https://doi.org/10.5817/PedOr2020-4-486 
boredom can motivate individuals to search for the resolution of their dissatisfactory situation and thus cultivate creativity (Bench \& Lench, 2013; van Tilburg \& Igou, 2012).

On the other hand, the impacts of the long-term use of poor boredom coping strategies at both the individual and societal levels are continually underestimated, although a number of studies document that boredom is related to a variety of negative and pathological phenomena, e.g., depression, neuroticism, somatization, emotional eating, gambling, addictive drug abuse, risky car driving, risky sexual behavior, hostility, delinquency and other forms of risky and unhealthy behavior (e.g., Blaszczynski, McConaghy, \& Frankova, 1990; Caldwell \& Smith, 1994, 1995; Dahlen et al., 2004; Heslop et al., 2010; Mercer-Lynn et al., 2011; Miller et al., 2014; Newberry \& Duncan, 2001; Sommers \& Vodanovich, 2000).

At school, neglected boredom is one of the most serious motivational problems complicating the entire educational process for both students and teachers, having a negative impact on the attitudes towards school and education of students across the globe. Neglected boredom problems and maladaptive coping strategies are transferred by students from school to their future work environment, and the long-term use of poor boredom coping strategies may have a negative impact on their quality of life.

Numerous research findings consistently show that boredom is the most frequently experienced emotion in the school environment (Goetz \& Hall, 2014). Pekrun (2006) outlines negative factors that are frequently connected with school boredom: low levels of cognitive resources, reduced learning motivation, incapability to continue task work and to use effective cognitive and especially meta-cognitive learning strategies, reduced capacity to regulate own working effort in order to reach goals, etc. Other studies confirm a negative relationship between boredom and various achievement characteristics, e.g., educational involvement (Watt \& Vodanovich, 1999) or the use of meta-cognitive strategies (Ahmed et al., 2013). Goetz and Hall (2014) refer to the consistent incidence of negative correlations between boredom and school results across different domains.

Even though boredom is a highly current research topic (it seems to be increasingly addressed across different domains), many questions remain unanswered, especially regarding the analysis of boredom sources and 
possible means of boredom coping. In the following text, we focus on boredom in a specific school environment, in which situations with certain types of constraints are often present, as happens later in working life. It seems that school boredom as a frustrating, stressful experience is an important part of so-called hidden curricula. In this sense, school can be perceived as a place where effective boredom coping could be cultivated (early recognition of boredom feelings, adequate coping strategies with respect to different school situations, awareness of one's own propensity to respond to certain boredom sources and/or to react to boredom in a specific way, etc.).

Most of the research in the field of educational boredom concerns academic issues. According to Farmer \& Sundberg (1986), the most boredom-prone population is adolescents, which is why we conducted our research with a population sample of secondary school students. We follow up with the earlier work of Pavelkova (2009), Goetz et al. (2013), Larson \& Richards (1991), Goetz et al. (2007), Nett, Goetz, \& Hall (2011), Caldwell, Darling, \& Payne (1999) and others.

In psychology, boredom has been conceptualized within a number of theoretical paradigms, such as psychodynamic (e.g., Fenichel, 1951), existential (e.g., Frankl, 1997), cognitive (e.g., Harris, 2000) or social-cognitive (e.g., Pekrun, 2006) paradigms. Different approaches can also be found across various psychology fields: social psychology (e.g., van Tilburg \& Igou, 2011), work psychology (e.g., Fisher, 1993), clinical psychology (e.g., Todman, 2003) or counseling psychology (e.g., Watt \& Ewing, 1996). Within the educational context, boredom is a subject addressed by Pavelkova (2002, 2009), Pekrun (2006), Vogel-Walcutt et al. (2012), Goetz et al. (2013), etc.

Even though a range of boredom factors has been examined, e.g., reduced attention capacity (Farmer \& Sundberg, 1986), monotony and routine aversion (Zuckerman, Eysenck, \& Eysenck, 1978), motivation and time work deficits (Vodanovich \& Rupp, 1999), many questions remain unanswered, especially those connected with causal relationships between the factors anticipating boredom and boredom consequences (Goetz \& Hall, 2014). Researchers also do not agree on the conceptualization of this complex psychological phenomenon, although particular accordance exists concerning the basic distinction between boredom proneness as a specific personal disposition (trait or chronic boredom) and reactive boredom linked to a specific situation (state boredom) (e.g., Vogel-Walcutt et al., 2012). 
It seems obvious that boredom cannot be simply defined as an absence of positive emotions or interest (Goetz \& Hall, 2014). Boredom rather seems to be a very complicated psychological construct that could be conceptualized as a specific emotion with a unique constellation of at least five components: physiological, affective, cognitive, motivational and behavioral/expressive (e.g., Pavelkova, 2009; Pekrun et al., 2010). However, even within this conceptualization, there is no accordance among researchers. While some researchers define boredom as a low-arousal emotion, others refer to it as a high-arousal affective state (Harris, 2000). Discussions also exist with regard to the valence of this experience, although the majority of researchers agree that boredom is rather negative than positive (Vogel-Walcutt et al., 2012).

Across research studies, we can find various attempts to define boredom in contrast to related psychological constructs: disinterest and dislike (Hill \& Perkins, 1985), fear and anxiety on one side and joy and pride on the other side (Pekrun, 2006), apathy, anhedonia and depression (Goldberg et al., 2011). Differences also exist in the theoretical and/or empirical understanding of boredom as a one-dimensional (e.g., Farmer \& Sundberg, 1986; Pekrun, 2006) or a multidimensional construct (e.g., Fahlman et al., 2013).

Research studies on boredom coping can be categorized according to different aspects, such as genre, methodology, context, and thematic focus (Pavelkova \& Urbanova, 2018). Within a specific school environment, little research attention has been given to this topic so far. There exist only a few boredom coping conceptualizations with different theoretical backgrounds. The conceptions of Hamilton, Haier, \& Buschbaum (1984) and Nett, Goetz, \& Daniels (2010) seem to be especially relevant and valuable for educational settings.

In the conceptualization of Hamilton et al. (1984), boredom coping is closely related to the ability to generate intrinsic enjoyment. While the intrinsic enjoyment construct is characterized by intensive concern, interest and absorbed attention, the construct of boredom coping reflects a certain disposition to restructure one's own perception and participation in potentially boring activities to reduce boredom and/or maximize the intrinsic enjoyment experience.

Boredom in this conception can be understood as a lack of engagement and enjoyment that appears when the attention of an individual must be 
strengthened by external incentives, such as salary or prestige. Boredom emerges in reaction to the presence of constraints that are typical of situations when an individual must do something that he does not want to or when he cannot do what he wants to. Following the theoretical boredom conception adopted from arousal theories (Csikszentmihalyi, 1975), the authors claim that individuals can cope with boredom effectively when they discover qualities similar to games within the boring task and are able to create specific rules for what they are doing. For example, someone may focus on the rhythm of his own movements when performing some monotonous physical activity. From this point of view, boredom coping does not consist of merely creating pictures and possibilities of what one could do but lies mainly in the personal capability to choose those that are constructive with regard to the current situation, can lead to a positive mood or can boost wellbeing. The type of activity is therefore irrelevant because we can project meaning onto it and make it a source of our intrinsic enjoyment, and if we do not, we may fall into boredom. Boredom coping in this conception reflects specific attentional capacity (ability to effectively control attention) across a variety of situations in different contexts (school, work, free time, etc.) (Hamilton et al., 1984).

The authors developed the Boredom Coping Scale, which is often used for research purposes, with subtle changes to the original scale (e.g., Fahlman, 2009; Game, 2007), but it seems that rather than measuring specific coping strategies, it measures general abilities that help individuals avoid the boredom experience, such as the capacity to remain attentive or think up interesting activities (Vodanovich, 2003). What seems to be of key value in this conception is the accent on the role of attentional control in the boredom experience as well as the boredom coping process.

In their boredom coping conceptualization, Nett et al. (2010) adapted existing, theoretically-grounded classification systems of stress coping strategies. This seems to be well-reasoned if we consider the boredom experience, especially in the school context, as potentially a highly frustrating and stressful experience ${ }^{2}$. Boredom is defined here as a specific emotion that is qualitatively different from the absence of joy and interest and that significantly relates to low levels of the perceived value of an activity or situation. In accordance with the above-mentioned component model of

2 About long-term boredom as a source of stress, refer to, e.g., Plummer (2010). 
emotions, boredom is described as an aversive state (affective component), within which the perception of time passing changes (cognitive component), accompanied by low arousal (physiological component), specific facial, vocal and postural expressions (expressive component) and motivation to change activities or leave the situation (motivational component) ${ }^{3}$.

The classification system adapted by Nett et al. (2010) consists of four types of coping strategies that can be differentiated along two dimensions. The first dimension reflects the main focus of strategies (approach versus avoidance), while the second dimension is related to the character of the strategy (cognitive versus behavioral). While approach strategies consist of the orientation towards solving a problem (boring situation), avoidance strategies are focused on avoidance or escape from a problem (boring situation).

Cognitive approach strategies include the change in perception of the current situation. A student uses this type of strategy when she says that even if the task is boring, it is important for her to do. Behavioral approach strategies consist of attempts to change the actual boring situation. For example, the student may ask the teacher to change the topic or activity in favor of more interesting topics. If the teacher complies with this requirement, the student can stop being bored. However, this strategy can have an effect even if the teacher does not comply because the teacher receives the information that students may be bored by the current activity. Cognitive avoidance strategies enable students to employ their mind with something different from the current boring task or activity (thinking of something that does not relate to the current task or activity, e.g., preparing homework in advance). Students using behavioral avoidance strategies do something else in a boring situation, for example, talk to a schoolmate or a person sitting next to them (Nett et al., 2010).

Based on this classification, Nett et al. (2010) constructed a Coping with Boredom Scale that is frequently used in current educational research (e.g., Nett et al., 2011; Daniels, Tze, \& Goetz, 2015; Eren \& Coskun, 2015; Tze et al., 2013). The scale was constructed for use in mathematics, but with subtle changes in instruction, it can also be used in other school domains. Boredom coping strategy types relate to the frequency of boredom at school

3 The physiological component is especially disputable in this regard since boredom could be connected also with high arousal (e.g., Fahlman et al., 2013). 
and other academic, emotional, motivational and cognitive aspects of school situations. The authors also identified three student groups using a specific combination of boredom coping strategies (Nett et al., 2010).

\section{Methods}

The purpose of this study is to contribute to a more comprehensive understanding of the boredom experience and especially boredom coping among Czech secondary school students. The main aim is to examine what types of boredom coping strategies students use in a specific educational environment and how these types of strategies relate to various aspects of students' state boredom experience and/or trait boredom. Additionally, relationships between, on one side, the preference for certain types of boredom coping strategies and grade point averages and, on the other side, some of the motivational characteristics of students are examined.

There are two groups of research questions:

Boredom experience: What aspects of the boredom experience at school are most salient for students in the research sample? How often do students experience boredom at school and in their free time? Is there a relationship between state boredom and the frequency of boredom at school and during free time? Is there a relationship between trait boredom and the frequency of boredom at school and during free time? Is there a relationship between trait and state boredom? Are there any differences between men and women in trait boredom, state boredom at school and boredom experience frequency at school and during free time?

Boredom coping: What types of boredom coping strategies do students use the most/the least? Is there a relationship between different coping types? Are there gender differences in boredom coping behavior at school? Is there a relationship between boredom frequency at school/during free time and different types of boredom coping strategies? Is there a relationship between various aspects of state boredom and different types of boredom coping strategies? Is there a relationship between trait boredom and different types of coping strategies? Is there a relationship between grade point average and different types of coping strategies? Is there a relationship between the types of learning motivation and different types of boredom coping strategies? 
The research sample consists of secondary school students $(n=460)$ (two grammar schools and two vocational secondary schools with different specializations: technical and educational), with a balanced representation of men $(\mathrm{n}=192)$ and women $(\mathrm{n}=268)$ with an average age of 17.3 years $(\mathrm{SD}=1.36$; range 15 to 24$)$.

To measure endogenous and exogenous boredom, an empirically constructed Boredom Proneness Scale $(\mathrm{n}=457)$ (Farmer \& Sundberg, 1986) and a multidimensional state boredom scale $(n=432)$ based on an integrative theoretical framework were used (Fahlman et al., 2013). Boredom coping strategies were measured using the Coping with Boredom Scale $(\mathrm{n}=328)^{4}$ (Nett et al., 2010). Motivational structure was assessed using the Learning Motivation Scale $(n=460)$ (Hrabal \& Pavelkova, 2010). The frequency of the boredom experience in the school and leisure context was assessed by two closed questions $(n=460)$. Regarding the foreign scales, existing Czech versions were used (Urbanova, 2016; Urbanova, 2018).

The Boredom Proneness Scale (BPS) captures the general disposition to experience boredom across a wide range of situations (trait boredom). According to authors, the scale emphasizes "one's connectedness with one's environment on many situational dimensions as well the ability to access adaptive resources and realize competencies" (Farmer \& Sundberg, 1986, p. 10). The BPS seems to be the first scale constructed exclusively for the purpose of boredom diagnostics. It contains 28 items with propositions, and respondents mark the level of their agreement on a seven-point Likert scale, where 1 = strongly disagree and $7=$ strongly agree. Example items are as follows: I have so many interests, I don't have time to do everything.; I often find myself with nothing to do - time on my hands. The scale consists of items with reverse coding. The original scale consists of 28 items with either yes or no responses, with internal consistency of $\alpha=0.79$, and retest reliability after one week was $\alpha=0.83$. Vodanovich \& Kass (1990) transferred the system of responses to a seven-point Likert scale. The internal consistency of this version across research studies ranges from $\alpha=0.79$ to $\alpha=0.91$ (Vodanovich \& Watt, 2016).

The Multidimensional State Boredom Scale (MSBS) captures five aspects of exogenous boredom, and the total score reflects the level of situational boredom. Scale construction is based on a theoretically and empirically

\footnotetext{
4 The CBS questionnaire could not be administered at one school due to time issues.
} 
grounded boredom definition that integrates psychodynamic, existential, attentional and arousal approaches to boredom. The scale includes these factors/subscales: disengagement, low arousal, high arousal, inattention and time perception (Fahlman et al., 2013). In the original study, the internal consistency was adequate for subscales ( $\alpha=0.80$ to $\alpha=0.88$ ) and for the total score $(\alpha=0.94)$, with similar results in other studies $(\alpha=0.91$ to $\alpha=0.95)$ for the total score and ( $\alpha=0.65$ to $\alpha=0.92)$ for subscales (Vodanovich \& Watt, 2016).

The MSBS consists of 29 items, and respondents mark the level of their agreement with the propositions on a seven-point Likert scale, where $1=$ strongly disagree and 7 = strongly agree. The disengagement subscale measures the unsatisfied desire to engage in satisfactory activity and consists of ten items, e.g., I am wasting time that would be better spent on something else. The low arousal subscale captures certain apathy and detachment and consists of five items, e.g., It appears that there's no one around me to talk to. The high arousal subscale also includes five items and measures feelings of strong agitation, e.g., Everything seems to be irritating me right now. The innate subscale reflects certain problems with attention in the boredom experience and consists of four items, e.g., My attention span is shorter than usual. The last subscale, time perception, measures the subjective perception of time passing slowly and includes five items, e.g., Time is passing slower than usual. The scale does not consist of items with reverse coding, and it can be used in experimental research because it is related to a concrete situation (Fahlman et al., 2013). In our study, respondents were asked to specifically describe boring situations in the school context and to keep this situation in their mind while working on this scale.

The Coping with Boredom Scale (CBS) includes 20 items divided into four subscales with adequate internal consistency ( $\alpha=0.83$ to 0.92). Each subscale measures one of the above-described types of boredom coping strategies and consists of five items (Nett et al., 2010). Each item offers a proposition that completes the same introductory statement ${ }^{5}$ : When I am bored with mathematics, .... Respondents mark the level of their agreement on a five-point Likert scale, where $1=$ strongly disagree and $5=$ strongly agree . Examples of items for subscales are as follows: cognitive approach: I make

5 For the purpose of this study, the introductory statement has been changed to the school context in general. 
myselffocus again because the issue is important. Cognitive avoidance: ...I think about my homework or something I have to study. Behavioral approach: ...I ask my instructor if we can do something else. Behavioral avoidance: ...I talk to the person sitting next to me.

The Learning Motivation Scale (LMS) consists of eight items capturing learning motivational structure. Each item measures different aspects of learning motivation and offers a proposition that completes the same introductory statement: When I exert an effort at school, it is because.... Respondents mark the level of their agreement on a five-point Likert scale, where 1 = strongly disagree and $5=$ strongly agree. The learning motivation aspects measured are social motivation (need for affiliation on one side and prestige on the other), cognitive motivation, moral motivation (school work perceived as a natural commitment), achievement motivation (both positive, characterized by the need for success, and negative, reflecting the need to avoid failure), instrumental motivation (connected to future advantages) and global motivation (reflecting the motivational push of the family; Hrabal \& Pavelkova, 2010).

Closed questions assessing the frequency of the boredom experience in different contexts were formulated as follows: Try to judge how often you experience boredom at school/in your free time. Respondents were asked to answer in both cases using a five-point Likert scale, where $1=$ never and $5=$ almost always.

Data were processed using a combination of descriptive and inductive statistical methods with the use of the SPSS program (ver. 26). With the exception of the BPS, in other methods and closed questions, there was no confirmed normal data distribution (Kolmogorov-Smirnov test). Therefore, nonparametric methods were employed, such as correlation analysis using Spearman's correlation coefficient and the Mann-Whitney test. To examine latent relationships among the variables, factor analysis using the principal components method was performed.

Data were processed using the following variables: boredom coping strategies subscales of the CBS (cognitive approach (CAP), cognitive avoidance (CAV), behavioral approach (BAP) and behavioral avoidance (BAV)); measured aspects of boredom: boredom proneness (BPS score), level of state boredom (MSBS total score), dimensions of state boredom at school (MSBS subscales: disengagement (DIS), low arousal (LA), high arousal (HA), time perception 
(TP) and inattention (IN)), frequency of the boredom experience at school (B_SCH) and during free time (B_FRT), type of learning motivation (social/ affiliation (LMS 1), social/prestige (LMS 2), cognitive (LMS 3), moral (LMS 4), positive achievement (LMS 5), negative achievement (LMS 6), instrumental (LMS 7) and global (LMS 8)), and grade point average (GPA).

\section{Results}

The results concerning the first group of research questions are shown in Table 1. Regarding students' boredom experience at school (MSBS), the research sample appears to be quite variable. The mean scores in most of the state boredom subscales as well as the total score indicate that boredom is experienced at school. The main boredom problems manifest in altered time flow perception, feelings of disengagement and attentional deficits. In contrast, neither of the aspects related to the level of arousal (high or low) seem to be salient. The MSBS subscales and total score values range from 1 to 7 , and the internal consistency for the subscales and the total score is adequate.

A statistically significant gender difference in state boredom experience appears within the total score $(\mathrm{Z}=-2.074, \mathrm{p}=0.038)$, with a larger mean rank of women (227.08) than men (201.83). Subscale score differences between men and women follow the same trend but without statistical significance.

In the research sample, students also differ in how often they experience boredom at school (B_SCH), while during free time (B_FRT), their scores are rather similar. Students experience boredom much more frequently at school than in their free time. While boredom at school is more commonly experienced by men, women score higher during free time boredom. These gender differences are not statistically significant but indicate an interesting trend.

For dispositional trait boredom (BPS), the research sample appears to be very consistent, without distinctive orientation or opposition (values range from 2.3 to 5.3) and adequate internal consistency, without statistically significant differences between men and women. 
Table 1

Boredom variables: basic psychometric information ( $M, S D)$, internal consistency $(\alpha)$ and correlations (Spearman's rho)

\begin{tabular}{cccccccccccc}
\hline & M & SD & A & MSBS & DIS & HA & LA & IN & TP & BPS & B_FRT \\
\hline MSBS & 4.74 & 1.03 & 0.94 & 1 & $0.88^{* *}$ & $0.78^{* *}$ & $0.69^{* *}$ & $0.73^{* *}$ & $0.73^{* *}$ & $0.25^{* *}$ & X \\
DIS & 5.03 & 1.11 & 0.85 & & 1 & $0.55^{* *}$ & $0.47^{* *}$ & $0.64^{* *}$ & $0.67^{* *}$ & $0.19^{* *}$ & X \\
HA & 4.12 & 1.34 & 0.79 & & & 1 & $0.64^{* *}$ & $0.49^{* *}$ & $0.38^{* *}$ & $0.24^{* *}$ & X \\
LA & 3.63 & 1.4 & 0.81 & & & & 1 & $0.35^{* *}$ & $0.28^{* *}$ & $0.24^{* *}$ & $\mathrm{X}$ \\
IN & 4.91 & 1.26 & 0.75 & & & & & 1 & $0.57^{* *}$ & $0.22^{* *}$ & $\mathrm{X}$ \\
TP & 5.76 & 1.45 & 0.93 & & & & & & 1 & $0.12^{*}$ & $\mathrm{X}$ \\
BPS & 3.7 & 0.55 & 0.73 & & & & & & & 1 & $\mathrm{X}$ \\
B_SCH & 3.69 & 0.92 & $\mathrm{X}$ & $0.22^{* *}$ & $0.23^{* *}$ & $0.14^{* *}$ & $0.13^{* *}$ & $0.27^{* *}$ & $0.14^{* *}$ & $0.39^{* *}$ & $0.13^{* *}$ \\
B_FRT & 1.89 & 0.74 & $\mathrm{X}$ & $0.10^{*}$ & $0.10^{*}$ & 0.09 & $0.13^{* *}$ & 0.06 & -0.01 & $0.26^{* *}$ & $\mathrm{X}$ \\
\hline
\end{tabular}

Note. MSBS = state boredom total score; dimensions of situational boredom: DIS = disengagement, $\mathrm{LA}=$ low arousal, $\mathrm{HA}=$ high arousal, $\mathrm{IN}=$ inattention, $\mathrm{TP}=$ time perception; $\mathrm{BPS}=$ dispositional boredom; B_SCH = boredom frequency at school, B_FRT = boredom frequency during free time $* * \mathrm{p}<0.01, * \mathrm{p}<0.05$

All of the significant relationships between boredom variables are positive. A weak to moderate correlation exists between trait boredom and boredom frequency at school $(\rho=0.39)$. Trait boredom also relates to the frequency of free time boredom $(\rho=0.26)$ (for which this is the only salient correlation) and all of the aspects of state boredom, especially the total score and both arousal subscales $(\rho=0.24$ to $\rho=0.25)$. School boredom frequency also relates to the state boredom total score and all state boredom subscales, especially to inattention $(\rho=0.27)$ and free time boredom frequency.

In the following text, the results connected to the second group of research questions are discussed. Table 2 shows the basic psychometric characteristics and intercorrelations of the CBS. The research sample seems to be quite variable, which indicates possible differences across individuals in boredom coping behavior at school. The students in this research sample appear to be mostly oriented toward behavioral avoidance strategies. In contrast, the type of coping preferred the least is the behavioral approach. It seems that when students in this research sample get bored at school, they start talking to their schoolmates rather than asking the teacher to change the topic. Values of both cognitive strategies types appear to be slightly above the average 
(avoidance higher than approach). Minimal and maximal values range from 1 to 6 , except regarding the behavioral approach, with a maximal value of 4.6. The internal consistency of the subscales ranges between $\alpha=0.76$ and $\alpha=0.92$, with the highest values for behavioral avoidance and the lowest values for behavioral approach.

Table 2

Coping with Boredom Scale - basic psychometric information (M, SD), internal consistency $(\alpha)$, scale intercorrelations (Spearman's rho)

\begin{tabular}{cccccccc}
\hline & $\mathrm{M}$ & $\mathrm{SD}$ & $\mathrm{A}$ & $\mathrm{CAP}$ & $\mathrm{BAP}$ & $\mathrm{CAV}$ & BAV \\
\hline CAP & 2.81 & 1 & 0.86 & 1 & 0.03 & 0.07 & $-0.21^{* *}$ \\
BAP & 1.91 & 0.8 & 0.76 & & 1 & $0.20^{* *}$ & $0.26^{* *}$ \\
CAV & 2.94 & 0.99 & 0.8 & & & 1 & $0.27^{* *}$ \\
BAV & 3.66 & 1.11 & 0.92 & & & & 1 \\
\hline
\end{tabular}

Note. $\mathrm{CAP}=$ cognitive approach, $\mathrm{BAP}=$ behavioral approach, $\mathrm{CAV}=$ cognitive avoidance, $\mathrm{BAV}=$ behavioral avoidance

$* * \mathrm{p}<0.01$

Regarding the scale intercorrelations, there were positive significant weak to moderate relationships between behavioral avoidance and, on the one hand, behavioral approach $(\rho=0.26)$ and, on the other hand, cognitive avoidance $(\rho=0.27)$. This indicates certain relationship between both behavioral strategies (tendency to interact with others) and between both avoidance strategies (tendency to escape from a boring situation). Additionally, a weakly to moderately significant negative relationship between cognitive approach and behavioral avoidance was detected $(\rho=-0.21)$. Between the behavioral approach and cognitive avoidance, a weakly to moderately significant positive correlation also seems to exist $(\rho=0.2)$.

Significant gender differences appear within the cognitive approach scale $(\mathrm{Z}=-2.614, \mathrm{p}=0.009)$, with larger mean rank of women (178.58) than men (151.25); the cognitive avoidance scale $(\mathrm{Z}=-2.685, \mathrm{p}=0.007)$, with larger mean rank of women (178.97) than men (150.89); and the behavioral approach scale $(Z=-2.119, p=0.034)$, with larger mean rank of men (175.2) than women (153.13). Men also scored higher on the behavioral approach, but the difference was not significant. These results indicate an interesting trend: women tend to react more to cognitive levels, and men prefer behavioral strategies. 
The correlations between the different types of boredom coping strategies and boredom frequency within different contexts, aspects of state boredom at school and trait boredom are shown in Table 3. The most and the strongest significant relationships were found between various boredom aspects and behavioral avoidance strategies. This type of strategy relates positively to reported frequency of boredom at school $(\rho=0.27)$ and state boredom at school (MSBS) $(\rho=0.34)$, especially the subscales of disengagement ( $\rho=0.39)$, inattention $(\rho=0.37)$, time perception $(\rho=0.35)$ and high arousal ( $\rho=0.19)$. This coping type seems to be the only one related to problems with attention and high arousal aspects of the boredom experience. It also seems that with regard to boredom occurrence at school, behavioral avoidance is a rather risky type of coping strategy.

On the other hand, the least risky type with regard to boredom occurrence at school appears to be the cognitive approach, with only negative relationships of weak to moderate significance with reported boredom frequency at school $(\rho=-0.27)$, total state boredom at school (MSBS) $(\rho=-0.14)$ and its subscales of time perception $(\rho=-0.19)$ and disengagement $(\rho=-0.18)$.

Table 3

Types of boredom coping strategies and different boredom aspects (Spearman's rho)

\begin{tabular}{cccccccccc}
\hline & BPS & MSBS & DIS & HA & LA & IN & TP & B_SCH & B_FRT \\
\hline CAP & -0.03 & $-0.14^{*}$ & $-0.18^{* *}$ & -0.05 & -0.03 & -0.10 & $-0.19^{* *}$ & $-0.27^{* *}$ & 0.07 \\
BAP & -0.03 & -0.02 & 0.00 & 0.08 & 0.03 & -0.02 & -0.10 & 0.09 & -0.01 \\
CAV & -0.08 & $0.16^{* *}$ & $0.17^{* *}$ & 0.11 & 0.11 & 0.11 & $0.14^{*}$ & 0.02 & 0.07 \\
BAV & 0.07 & $0.34^{* *}$ & $0.39^{* *}$ & $0.19^{* *}$ & 0.07 & $0.37^{* *}$ & $0.35^{* *}$ & $0.27^{* *}$ & -0.04 \\
\hline
\end{tabular}

Note. $\mathrm{CAP}=$ cognitive approach, $\mathrm{BAP}=$ behavioral approach, $\mathrm{CAV}=$ cognitive avoidance, $\mathrm{BAV}=$ behavioral avoidance; MSBS = situational boredom total score, DIS = disengagement, LA = low arousal, $\mathrm{HA}=$ high arousal, IN = inattention, TP = time perception; BPS = dispositional boredom; B_SCH $=$ boredom frequency at school, B_FRT $=$ boredom frequency during free time ** $\mathrm{p}<0.01, * \mathrm{p}<0.05$

Another rather risky type of coping with regard to boredom at school seems to be the second avoidance strategy type, which is cognitive avoidance. In this coping type, we can see positive relationships of weak to moderate significance with the total state boredom score (MSBS) $(\rho=0.16)$ and its subscales of disengagement $(\rho=0.17)$ and time perception $(\rho=0.14)$. The 
perception of time passing slowly and feelings of disengagement seem to be of key importance in both cognitive boredom coping types (positive relation to avoidance, negative relation to approach).

The behavioral approach type of boredom coping does not seem to be related to any aspect of the boredom experience. As shown in Table 4, this is also the only coping type that is significantly related to school performance. With its positive ${ }^{6}$ relation to grade point average (GPA), this type of coping behavior appears to be rather risky.

It seems interesting that low arousal does not appear to fit the state boredom experience related to any type of boredom coping. Additionally, neither trait boredom (BPS) nor free time boredom frequency had a significant relation to any of the boredom coping types.

Table 4 also shows the relationships between the boredom coping types and learning motivational characteristics of students in our research sample. Most of the positive relationships of weak to moderate significance between coping via a cognitive approach and positive achievement motivation ( $\rho=0.27)$, moral motivation $(\rho=0.27)$, cognitive motivation $(\rho=0.16)$, instrumental motivation $(\rho=0.16)$, and achievement motivation in its negative, fear form $(\rho=0.15)$. It seems that students scoring high in coping via the cognitive approach need to be successful in what they do and tend to perceive schoolwork as their natural duty. The cognitive approach also seems to be related to the need to think and learn and to the ability to see further advantages of schoolwork. To a certain extent, the need to avoid failure plays the role of a risky characteristic connected to this coping type.

What seems to be of key importance in both cognitive coping types is the actualized need for success (positive significant relationship between positive achievement motivation and cognitive avoidance coping $(\rho=0.12)$ ).

In contrast, the only negative significant relationship appears between coping by behavioral avoidance and cognitive motivation $(\rho=-0.12)$. It seems that students who tend to communicate with their classmates when they get bored also have a very low need to learn new things and think.

$6 \quad$ Negative values indicate higher scores in grade point average. 
Table 4

Types of boredom coping strategies, grade point average and learning motivational characteristics (Spearman's rho)

\begin{tabular}{cccccccccc}
\hline & GPA & LMS_1 & LMS_2 & LMS_3 & LMS_4 & LMS_5 & LMS_6 & LMS_7 & LMS_8 \\
\hline CAP & 0.02 & 0.06 & 0.10 & $0.16^{* *}$ & $0.27^{* *}$ & $0.27^{* *}$ & $0.15^{* *}$ & $0.16^{* *}$ & 0.08 \\
BAP & $0.16^{* *}$ & -0.04 & 0.05 & -0.02 & 0.01 & -0.01 & 0.06 & 0.05 & 0.06 \\
CAV & -0.05 & -0.08 & -0.02 & -0.02 & 0.05 & $0.12^{*}$ & 0.05 & 0.07 & -0.03 \\
BAV & 0.08 & -0.05 & -0.01 & $-0.12^{*}$ & -0.03 & 0.04 & 0.02 & 0.00 & 0.00 \\
\hline
\end{tabular}

Note. $\mathrm{CAP}=$ cognitive approach, $\mathrm{BAP}=$ behavioral approach, $\mathrm{CAV}=$ cognitive avoidance, $\mathrm{BAV}=$ behavioral avoidance; GPA = grade point average; learning motivation types: LMS 1 = social/ affiliation, LMS $2=$ social/prestige, LMS $3=$ cognitional, LMS $4=$ moral $/$ diligence, LMS $5=$ achievement/positive - need for success, LMS 6 = achievement/fear - need for failure avoidance, LMS 7 = instrumental, LMS 8 = global/family motivational pressure

** $\mathrm{p}<0.01, * \mathrm{p}<0.05$

In addition to these findings, a factor analysis based on the principal component method was used to obtain a more complex view of data with an insight into possible latent relationships among the variables. Based on the Scree plot, seven factors accounting for $63 \%$ of the total variance were detected. Rotation was not suitable in this case. Factor loadings of a value higher than 0.3 are shown in Table 5.

The boredom and disturbance at school factor explains 19\% of the variance and is saturated by a specific disposition to become bored (trait boredom) together with high levels of school state boredom and a high frequency of the boredom experience reported at school. In state boredom, all of the measured aspects seem to be experienced (feelings of not being able to engage in a satisfying activity, problems with attention, perception of time passing by slowly, high arousal and agitation, as well as low arousal and apathy). This boredom picture seems to be related to behavioral avoidance coping behavior (talking to classmates, etc.). Saturation by grade point average and learning motivation needs is missing. 
Table 5

Factor matrix

\begin{tabular}{|c|c|c|c|c|c|c|c|}
\hline & $\begin{array}{c}\text { Boredom and } \\
\text { disturbance } \\
\text { at school }\end{array}$ & Motivational & $\begin{array}{c}\text { General } \\
\text { passivity }\end{array}$ & $\begin{array}{l}\text { Compliance } \\
\text { with school }\end{array}$ & $\begin{array}{l}\text { Fear of } \\
\text { failure }\end{array}$ & $\begin{array}{c}\text { On the } \\
\text { surface or } \\
\text { disconnection }\end{array}$ & $\begin{array}{l}\text { Need } \\
\text { for } \\
\text { contact }\end{array}$ \\
\hline CAP & & 0.39 & & 0.41 & 0.32 & & \\
\hline BAP & & & & -0.37 & 0.39 & 0.48 & 0.37 \\
\hline CAV & & & -0.47 & & & 0.45 & \\
\hline BAV & 0.50 & & -0.30 & -0.48 & & & \\
\hline BPS & 0.42 & & 0.61 & & & & \\
\hline DIS & 0.85 & & & & & & \\
\hline HA & 0.75 & & & & & & \\
\hline LA & 0.69 & & & 0.34 & & & \\
\hline IN & 0.81 & & & & & & \\
\hline $\mathrm{TP}$ & 0.71 & & & & & & \\
\hline B_SCH & 0.47 & & 0.37 & -0.35 & & & \\
\hline B_FRT & & & 0.36 & 0.43 & & 0.40 & -0.35 \\
\hline LMS 1 & & 0.41 & & & -0.47 & & 0.34 \\
\hline LMS 2 & & 0.43 & & & -0.37 & 0.45 & \\
\hline LMS 3 & & & -0.41 & 0.38 & 0.44 & & \\
\hline LMS 4 & & 0.72 & & & & & \\
\hline LMS 5 & & 0.64 & & & & & \\
\hline LMS 6 & & 0.37 & & & 0.43 & & \\
\hline LMS 7 & & 0.64 & & & & & \\
\hline LMS 8 & & 0.55 & & & & & \\
\hline GPA & & & & -0.35 & 0.41 & & 0.50 \\
\hline
\end{tabular}

Note. $\mathrm{CAP}=$ cognitive approach, $\mathrm{BAP}=$ behavioral approach, $\mathrm{CAV}=$ cognitive avoidance, $\mathrm{BAV}=$ behavioral avoidance; BPS = dispositional boredom; situational boredom dimensions: DIS = disengagement, LA = low arousal, $\mathrm{HA}=$ high arousal, $\mathrm{IN}=$ inattention, $\mathrm{TP}=$ time perception; B_SCH = boredom frequency at school, B_FRT $=$ boredom frequency during free time; learning motivation types: LMS 1 = social/affiliation, LMS $2=$ social/prestige, LMS $3=$ cognitional, LMS $4=$ moral/diligence, LMS 5 = achievement/positive - need for success, LMS $6=$ achievement/fear need for failure avoidance, LMS 7 = instrumental, LMS 8 = global/family motivational pressure; $\mathrm{GPA}=$ grade point average

The motivational factor explains $12 \%$ of the variance and combines most of the learning motivational indicators with coping via the cognitive approach. Strong motivation for schoolwork seems to be dominant within this factor, 
especially high levels of conscientiousness related to school work, the need to achieve success and the capacity to perceive remote advantages of current activities (e.g., better school results will lead to a good job in the future) rather than the cognitive motivation to think and learn new things. High levels of positive learning motivation together with awareness of the importance of the current school task or activity seem to be supportive of coping with boredom even before it appears (there is no saturation by any boredom variable in this factor). Again, this factor is not saturated by the grade point average.

The general passivity factor, explaining $8 \%$ of the variance, is associated with high levels of declared boredom frequency indicators both at school and during free time, together with the personal disposition to be bored (trait boredom). This factor is also saturated by negative loadings of cognitive learning motivation and both types of boredom coping by avoidance behavior. This factor is not saturated by school state boredom and school performance.

The compliance with school factor explains $7 \%$ of the variance and consists of high levels of, on one side, declared boredom during free time and low arousal in the boredom experience and, on the other side, cognitive motivation in terms of the need to think and learn, cognitive approach coping and good grade point average, together with negative loadings of both behavioral coping types and reported boredom frequency at school. This factor is not saturated by trait boredom.

The fear of failure factor, explaining $7 \%$ of the variance, is saturated by none of the boredom variables but offers an interesting picture of learning motivation, boredom coping and grade point average: high levels of cognitive motivation, negative (fear of failure) achievement motivation and both approach coping strategies together with negative loadings of both social motivations (need for prestige and need for affiliation) and school performance.

The surface or disconnection factor explains $6 \%$ of the variance and is associated with high levels of reported boredom frequency during free time, the need for social prestige as a motivational factor for schoolwork, and the behavioral approach and cognitive avoidance boredom coping strategies. This factor is not saturated by school or trait boredom and school performance.

The need for contact factor, explaining the last $5 \%$ of the variance, is associated with poor school performance, high levels of the need for affiliation as a source 
of learning motivation and boredom coping via the behavioral approach, and negative loadings of declared frequency of boredom during free time, with no other (either positive or negative) boredom variables saturated.

\section{Discussion}

The research results indicate that school boredom problems exist among secondary students in our research sample and that those problems are both situational and dispositional. Feelings of boredom are more frequently experienced at school than free time. School boredom manifests mostly in an unsatisfied desire to engage in satisfactory activity, altered time flow perception and attentional problems.

For boredom coping, the students in the research sample are mostly oriented toward behavioral avoidance coping, while behavioral approach strategies seem to be used the least. These two main tendencies are in concordance with the study of Nett et al. (2010). However, in our research sample, we can see lower levels of cognitive approach strategies and higher levels of all other coping types than observed in the original German study. It seems that compared to students in the German study, students in the Czech research sample prefer not only behavioral but also cognitive avoidance (escape from the boring situation either by talking to schoolmate or by thinking about something else) to cognitive "reappraisal" of the boring task.

In this study, significant intercorrelations between the subscales (negative between the cognitive approach and behavioral avoidance and positive between the two behavioral scales) were detected that were not confirmed in the original study (Nett et al., 2010) but seem to follow the theoretically expected directions.

Correlation analysis also indicates that with regard to boredom occurrence at school, the least risky coping type appears to be the cognitive approach, while the most risky coping type seems to be behavioral avoidance. Additionally, the second avoidance coping type (cognitive) relates positively to boredom. It seems that one of the most serious maladaptive school boredom coping problems within the Czech sample is the tendency to systematically employ avoidance and escape behavior that does not help students solve their problem and in fact makes the situation worse. 
If we consider the relationship with grade point average, the behavioral approach seems to be a rather risky coping type. Factor analysis confirms these trends and further indicates a positive relation of the grade point average to the cognitive approach (students who prefer the cognitive approach have better school results) and a negative relation to behavioral avoidance (students who prefer the behavioral approach have worse school results).

From the perspective of learning motivation, it seems that the key characteristics of good school boredom coping are high levels of positive achievement motivation in terms of the need for success, conscientiousness with regard to schoolwork, the capability to successfully overcome tasks that are not very interesting, instrumental motivation in terms of the capability to perceive future advantages of schoolwork and especially cognitive motivation (which seems to have a key supportive role in boredom coping at school). The paradox with cognitive motivation consists of that it does not need to be always highly actualized, but it must be at least present to a certain level.

The results of factor analysis further indicate that different constellations of measured boredom aspects and coping strategies together with motivational characteristics may be associated with various types of students. For example, the preference of the cognitive approach seems to associate different groups of students with a specific capability to search for and find personal value in schoolwork and to exert certain cognitive effort, but these students differ in various characteristics; e.g., some report no boredom occurrence at all and are strongly motivated to do schoolwork, others show the need for (and compliance with) the school structure and report being bored in their free time, and for another group, fear of failure seems to be a salient school motivational factor.

This diversity within certain types of boredom coping behavior can also be seen in other coping types. For example, the behavioral approach also seems to be associated with different groups of students. Students may prefer to ask the teacher to change the boring topic or activity when they get bored because they fail to find personal value in it and are no longer able to exert further cognitive effort, because they perceive that the source of boredom is outside of themselves and are simply not willing to exert any cognitive effort (if the problem is not solved for them, they tend to escape the boring situation at least in their thoughts), or because what is the most important for them at school is contact with the teacher. 
It seems obvious that students do not use only one type of boredom coping across various situations, but they dispose of certain repertoires of coping behavior. When examining this problem, Nett et al. (2010) used latent profile analysis to identify three groups of students with similar compositions of boredom coping strategies related to different emotional, motivational, cognitive and other characteristics distributed within the research sample. This seems to be a valuable approach to examine interindividual differences in coping behavior, although it has certain limitations.

What seems to be of key importance here and what complicates the whole issue is the fact that within each boredom coping behavior type, positive and negative connotations may be present. For example, regarding coping by behavioral avoidance: what do students talk to their schoolmates about during a boring class? Their discussion could be either on or off the lesson topic. In some cases, talking to a schoolmate during the classes can represent a form of provocation towards the teacher. Students can also differ not only in how many strategies they use but also in how often and in what types of situations they use them to cope with boredom at school.

Although the boredom coping strategies classification of Nett et al. (2010) seems functional in this study, it appears to be reductive to a certain extent. Some of the important and interesting aspects of reality cannot be captured using this classification. A more comprehensive examination of what is happening against a background of different reactions to boredom in an effort to cope with this mainly aversive experience at school is needed.

For the purpose of this study, quantitative methodology was used to obtain some basic insight into the mutual relationships between various aspects of boredom, which is to a certain extent reductive. Although the questionnaire is the most often used method in this field of research, this method entails a number of limitations (the need to choose among the predefined claims, social desirability, retrospective assessment of past experience, etc.). To capture the boredom experience and specific boredom coping mechanisms in its broader complexity, a qualitative approach or even an experimental design or other "in vivo" methods (e.g., experience sampling) should also be employed.

The possibilities to empirically grasp the boredom experience and boredom coping mechanisms are very complicated in general because there is no conformity between various conceptualizations of these issues. It is also 
very complicated, especially in the school context, to distinguish between the cases where boredom truly occurs and where it is just a part of certain broader, mostly negative general attitude.

Further systematic research in the field of boredom coping is needed. For example, different types of coping strategies should be examined with regard to related types of school situations. Additionally, different factors on both sides of the situation (presence of constraints, impossibility of leaving the situation, teaching style, personality of the teacher, ambitiousness and attractivity of the subject matter, etc.) and personality (volitional, motivational and attitudinal characteristics, actual experience, attentional problems, temperament, capability to find the value in potentially boring tasks, etc.) in their mutual, reciprocal relationship should be examined.

Additionally, the question of possible relationships between the preference of behavioral coping strategies and externalizing problems related to boredom (e.g., disturbance in class, behavior malfunction, delinquency) and between the preferred cognitive coping strategies and internalizing problems connected with boredom (apathy, emotional eating, depression) should be answered.

\section{References}

Ahmed, W., van der Werf, G., Kuyper, H., \& Minnaert, A. (2013). Emotions, self-regulated learning, and achievement in mathematics: A growth curve analysis. Journal of Educational Psychology, 105(1), 150-161.

Bench S. W., \& Lench H. C. (2013). On the function of boredom. Behavioral sciences, 3(3), 459-472.

Blaszczynski, A., McConaghy, N., \& Frankova, A. (1990). Boredom proneness in pathological gambling. Psychological Reports, 67(1), 35-42.

Caldwell, L. L., \& Smith, E. A. (1994). Leisure and mental health of high risk adolescents. Leisure and Mental Health, 1, 330-345.

Caldwell, L. L., \& Smith, E. A. (1995). Health behaviors of leisure alienated youth. Society and Leisure, 18(1), 143-156.

Caldwell, L. L., Darling, N., Payne, L. L., \& Dowdy, B. (1999). “Why are you bored?”: An examination of psychological and social control values of boredom among adolescents. Journal of Leisure Research, 31(2), 103-121.

Csikszentmihalyi, M. (1975). A theoretical model of enjoyment. In M. Csikszentmihalyi, Beyond boredom and anxiety (pp. 35-54). San Francisco, CA: Jossey-Bass.

Dahlen, E. R., Ryan, M. C., Ragan, K., \& Kuhlman, M. M. (2004). Boredom proneness in anger and aggression: Effects of impulsiveness and sensation seeking. Personality and individual differences, 37(8), 1615-1627. 
Daniels, L. M., Tze, V. M., \& Goetz, T. (2015). Examining boredom: Different causes for different coping profiles. Learning and Individual Differences, 37, 255-261.

Eren, A., \& Coskun, H. (2015). Time perspectives and boredom coping strategies of undergraduate students from Turkey. Educational Research for Policy and Practise, 14(1), 53-75.

Fahlman, S. A. (2009). Does a lack of life meaning cause boredom? Results from psychometric, longitudinal and experimentlal analyses. Journal of Social and Clinical Psychology, 28(3), 307-340.

Fahlman, S. A., Mercer-Lynn, K. B., Flora, D. B., \& Eastwood, J. D. (2013). Development and validation of the multidimensional state boredom scale (MSBS). Assessment, 20(1), 68-85.

Farmer, R., \& Sundberg, N. D. (1986). Boredom proneness - The development and correlates of a new scale. Journal of Personality Assessment, 50(1), 4-17.

Fenichel, O. (1951). On the psychology of boredom. In D. Rappaport (Ed.), Organization and pathology of thought (pp. 349-361). New York, Columbia University Press.

Fisher, C. D. (1993). Boredom at work: A neglected concept. Human Relations, 46(3), 395-417.

Frankl, V. (1997). Vůle ke smyslu: vybrané přednášky o logoterapii. Brno: Cesta.

Game, A. M. (2007). Workplace boredom coping: Healh, safety, and HR implications. Personnel Review, 36, 701-721.

Goetz, T., Frenzel, A., Pekrun, R., Hall, N.C., \& Ludtke, O. (2007). Between and within domain relations of students' academic emotions. Journal of Educational Psychology, 99(4), 715-733.

Goetz, T., Frenzel, A., Hall, N. C., Nett, U. E., Pekrun, R., \& Lipnevich, A. A. (2013). Types of boredom: An experience sampling approach. Motivation and Emotion, 38(3), 401-419.

Goetz, T., \& Hall, N. C. (2014). Academic boredom. In R. Pekrun \& L. Linnenbrink-Garcia (Eds.), International Handbook of Emotions in Education (pp. 311-330). Routledge.

Goldberg, J. K., Eastwood, J. D., LaGuardi, J., \& Danckert, J. (2011). Boredom: An emotional experience distinct from apathy, anhedonia, or depression. Journal of Social and Clinical Psychology, 30(6), 647-666.

Hamilton, J. A., Haier, R. S., \& Buchsbaum, M. S. (1984). Intrinsic enjoyment and boredom coping scales: Validation with personality, evoked potential, and attention measures. Personality and Individual Differences, 5(2), 183-193.

Harris, M. B. (2000). Correlates and characteristics of boredom proneness and boredom. Journal of Applied Social Psychology, 30(3), 576-598.

Heslop, S., Harvey, J., Thorpe, N., \& Mulley, C. (2010). Factors that comprise driver boredom and their relationships to preferred driving speed and demographic variables. Transportation Planning and Technology, 33(1), 75-89.

Hill, A. B., \& Perkins, R. E. (1985). Towards a model of boredom. British Journal of Psychology, 76(2), 235-240.

Hrabal, V. \& Pavelkova, I. (2010). Jaký jsem učitel. Praha: Portál.

Larson, R. W., \& Richards, M. H. (1991). Boredom in the middle school years: Blaming schools versus blaming students. American Journal of Education, 99(4), 418-433.

Mercer-Lynn, K. B., Flora, D. B., Fahlman, S. A., \& Eastwood, J. D. (2011). The measurement of boredom: Differences between existing self-report scales. Assessment, 20(5), 585-596. 
Miller, J., Caldwell, L., Weybright, E. H., Smith, E. A., Vergnani, T., \& Wegner, L. (2014). Was Bob Seger right? Relation between boredom in leisure and (risky) sex. Leisure Science, 36(1), $52-67$.

Nett, U. E., Goetz, T., \& Daniels, L. M. (2010). What to do when feeling bored? Students' strategies for coping with boredom. Learning and Individual Differences, 20(6), 626-638.

Nett, U. E., Goetz, T., \& Hall, N. C. (2011). Coping with boredom in school: An experience sampling perspective. Contemporary Educational Psychology, 36, 49-59.

Newberry, A. L., \& Duncan, R. D. (2001). Roles of boredom and life goals in juvenile delinquency. Journal of Applied Social Psychology, 31(3), 527-541.

Pavelková, I. (2002). Motivace žáků k učení. Perspektivní orientace žáků a časový faktor v žákovské motivaci. Praha: PedF UK.

Pavelkova, I. (2009). Nuda ve škole. In R. Váňová \& H. Krykorková (Eds.), Učitel v současné škole (pp. 107-118). Prague: Karolinum.

Pavelkova, I., \& Urbanova, D. (2018). Nuda v edukačním kontextu: teoretické konceptualizace a výzkumné metody. Československá psychologie, 62(4), 350-365.

Pekrun, R. (2006). The control-value theory of achievement emotions: Assumptions, corollaries, and implications for educational research and practice. Educational Psychology Review, 18(4), 315-341.

Pekrun, R., Daniels, L. M., Goetz, T., \& Stupnisky, R. H. (2010). Boredom in achievement settings: Exploring control-value antecedents and performance outcomes of a neglected emotion. Journal of Educational Psychology, 102(3), 531-549.

Plummer, D. M. (2010). Helping children to cope with change, stress and anxiety: A photocopiable book paperback. London: Jessica K. Publishers.

Sommers, J., \& Vodanovich, S. J. (2000). Boredom proneness: Its relationship to psychologicaland physical-health symptoms. Journal of Clinical Psychology, 56(1), 149-55.

Todman, M. (2003). Boredom and psychotic disorders: Cognitive and motivational issues. Psychiatry, 66(2), 146-167.

Tze, V. M., Daniels, L. D., Klassen, R. M., \& Li, J. C.-H. (2013). Canadian and Chinese university students' approaches to coping with academic boredom. Learning, 23, 32-43.

Urbanova, D. (2016). Časová perspektiva a nuda. (Unpublished bachelor's thesis). Prague: Charles university in Prague, Department of Education.

Urbanova, D. (2018). Copingové strategie u nudy. (Unpublished diploma's thesis). Prague: Charles university in Prague, Department of Education.

Van Tilburg, W. A., \& Igou, E. R. (2011). On boredom and social identity. A pragmatic meaningregulation approach. Personality and Social Psychology Bulletin, 37(12), 1679-91.

Van Tilburg, W. A., \& Igou, E. R. (2012). On boredom: Lack of challenge and meaning as distinct boredom experiences. Motivation and Emotion, 36(2), 181-194.

Vodanovich, S. J. (2003). Psychometric measures of boredom: A review of the literature. Journal of Psychology, 137(6), 569-595.

Vodanovich, S. J., \& Kass, S. J. (1990). A factor analytic study of the Boredom Proneness Scale. Journal of Personality Assessment, 55(1-2), 115-123.

Vodanovich, S. J., \& Watt, J. D. (2016). Self-Report measures of boredom: An updated review of the literature. The Journal of Psychology, 150(2), 196-228. 
Vodanovich, S. J., \& Rupp, D. E. (1999). Are procrastinators prone to boredom? Social Behavior and Personality: An International Journal, 27(1), 11-16.

Vogel-Walcutt, J. J., Fiorella, L., Carper, T., \& Schatz, S. (2012). The definition, assessment, and mitigation of state boredom within educational settings: A comprehensive review. Educational Psychology Review, 24(1), 89-111.

Watt, J. D., \& Ewing, J. E. (1996). Toward the development and validation of a measure of sexual boredom. Journal of Sex Research, 33(1), 57-66.

Watt, J. D., \& Vodanovich, S. (1999). Boredom proneness and psychosocial development. The Journal of Psychology, 133(3), 303-314.

Zuckerman, M., Eysenck, S. B., \& Eysenck, H. J. (1978). Sensation seeking in England and America: Cross-cultural, age and sex comparisons. Journal of Consulting and Clinical Psychology, 46(1), 139-149.

\section{Authors}

Mgr. Ing. Denisa Urbanová, Charles University, Faculty of Education, Department of Psychology, Myslíkova 7, 11000 Prague 1, e-mail: asined.urbanova@gmail.com

doc. PhDr. Isabella Pavelková, CSc., Charles University, Faculty of Education, Department of Psychology, Myslíkova 7, 11000 Prague 1, e-mail: jfpavelka@volny.cz

\section{Zvládání nudy v kontextu stř̌edoškolského vzdělávání}

Abstrakt: Článek se zabývá problematikou nudy a zejména jejího zvládání u žáků českých středních škol (n = 460). Były prověřovány vztahy mezi uváděnou frekvencí nudy, různými aspekty situační nudy ve škole, skłonem k nudě, studijním průměrem a učebně motivačními charakteristikami na straně jedné a různými typy strategii zvládání nudy na straně druhé. Data była získána s využitím Škály sklonu k nudě (BPS), Multidimenzionální škály situační nudy (MSBS), Škály zvládání nudy (CBS), Dotazníku učební motivace (DUM) a uzavřených otázek. Data była zpracována s využitím metod popisné a induktivní statistiky. Vzhledem k prožívání nudy ve škole a studijnímu průměru były identifikovány více a méně rizikové skupiny copingových strategií. Klíčovými faktory podporujícími adaptivní způsoby zvládání nudy se ukazují být schopnost nalézat osobní hodnotu v potenciálně nudných aktivitách a vyvíjet určité kognitivní úsilí spolu s pozitivní výkonovou motivací a svědomitostí při školní práci. Jako hlavní podpůrný faktor se navíc jeví alespoň určitá míra rozvinutosti poznávací motivace. Rizikovým faktorem vzhledem ke spíše maladaptivním typům reakcí na nudu se jeví tendence systematicky zapojovat vyhýbavé či dokonce únikové chování. Výsledky naznačují, že problematika školní nudy a jejího zvládání je velmi komplikovaná, a přinášejí četné implikace pro budoucí výzkum v této oblasti.

Klíčová slova: nuda, školní nuda, zvládání nudy, učební motivace 